This is a self-archived version of an original article. This version may differ from the original in pagination and typographic details. Author(s): Kohler, Florent; Holland, Timothy. G.; Kotiaho, Janne Sakari; Desrousseaux,
Maylis; Potts, Matthew D.

Title: Embracing diverse worldviews to share planet Earth

Year: 2019

Version: Accepted version (Final draft)

Copyright: (C) 2019 Society for Conservation Biology

Rights: In Copyright

Rights url: http://rightsstatements.org/page//nC/1.0/?language=en

Please cite the original version:

Kohler, F., Holland, T. G., Kotiaho, J. S., Desrousseaux, M., \& Potts, M. D. (2019). Embracing diverse worldviews to share planet Earth. Conservation Biology, 33(5), 1014-1022.

https://doi.org/10.1111/cobi.13304 


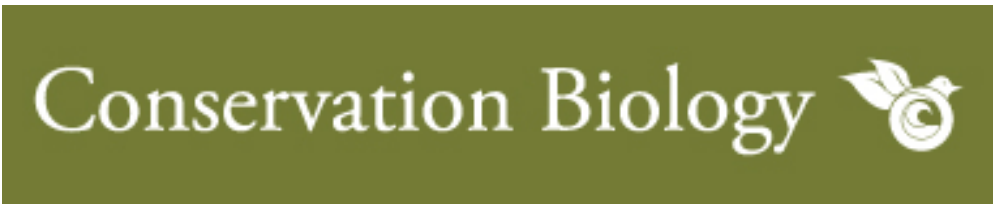

\title{
Embracing diverse worldviews to share planet Earth
}

\author{
F. Kohler, ${ }^{1 *}$ T.G. Holland, ${ }^{2}$ J.S. Kotiaho, ${ }^{3,4}$ M. Desrousseaux, ${ }^{5}$ and M.D. Potts (D) 1 \\ ${ }^{1}$ Interactions Culturelles et Discursives, Université de Tours, 3 rue des Tanneurs, 37000 Tours, France \\ ${ }^{2}$ Department of Environmental Science, Policy, and Management, University of California, Berkeley, 130 Mulford Hall, Berkeley, CA \\ 94720-3114, U.S.A. \\ ${ }^{3}$ Department of Biological and Environmental Science, University of Jyväskylä, P.O. Box 35, 40014, Jyväskylä, Finland \\ ${ }^{4}$ School of Resource Wisdom, University of Jyväskylä, P.O. Box 35, 40014, Jyväskylä, Finland \\ ${ }^{5}$ CNAM-ESGT, Laboratory of Geomatics and Property, Le Mans, France
}

\begin{tabular}{|c|c|}
\hline Abstract: & $\begin{array}{l}\text { Leading societies toward a more sustainable, equitably shared, and } \\
\text { environmentally just future requires elevating and strengthening } \\
\text { conversations on the non-material and perhaps unquantifiable values of } \\
\text { non-human nature to humanity. Many of the sustainability solutions } \\
\text { proposed by scientists and decision-makers are based on a human- } \\
\text { centered perspective that put at risk non-utilitarian aspects of } \\
\text { ecosystems and species. Our essay explores the wide global diversity of } \\
\text { perspectives on the human-nature relationship and argues that our best } \\
\text { chance for effective conservation is to take a pluralistic approach that } \\
\text { engages seriously with the worldviews of all stakeholders. We also } \\
\text { highlight how many worldviews-particularly those in many indigenous } \\
\text { cultures-place a higher value on the spiritual and non-material aspects } \\
\text { than what is often represented by the discourse surrounding Western } \\
\text { conservation policy. We discuss how alternative framings of human- } \\
\text { nature relationships that recognize nature's intrinsic value can be } \\
\text { powerful motivators for social change and for local-scale conservation } \\
\text { efforts. At a national and international level, changing ethical framings of } \\
\text { our relationship with nature have already started influencing our } \\
\text { conceptions of human rights relating to the environment and of the } \\
\text { rights of nature itself; this has led to an increased role of the judiciary in } \\
\text { promoting environmental sustainability and in promoting justice for } \\
\text { those groups who are most often affected by environmental harms. It is } \\
\text { our hope that this essay will motivate the scientific community to change } \\
\text { its own perception of what a sound and sustainable relationship between } \\
\text { humanity and other species should be and will help citizens become } \\
\text { active environmental subjects, connected to the ecosystems around } \\
\text { them. }\end{array}$ \\
\hline
\end{tabular}




\section{Embracing diverse worldviews to share planet Earth}

\section{Abstract}

3 Leading societies toward a more sustainable, equitably shared, and environmentally just future

4 requires elevating and strengthening conversations on the non-material and perhaps unquantifiable

5 values of non-human nature to humanity. Many of the sustainability solutions proposed by

6 scientists and decision-makers are based on a human-centered perspective that put at risk non-

7 utilitarian aspects of ecosystems and species. Our essay explores the wide global diversity of

8 perspectives on the human-nature relationship and argues that our best chance for effective

9 conservation is to take a pluralistic approach that engages seriously with the worldviews of all

10 stakeholders. We also highlight how many worldviews-particularly those in many indigenous

11 cultures-place a higher value on the spiritual and non-material aspects than what is often

12 represented by the discourse surrounding Western conservation policy. We discuss how alternative

13 framings of human-nature relationships that recognize nature's intrinsic value can be powerful

14 motivators for social change and for local-scale conservation efforts. At a national and

15 international level, changing ethical framings of our relationship with nature have already started

16 influencing our conceptions of human rights relating to the environment and of the rights of nature

17 itself; this has led to an increased role of the judiciary in promoting environmental sustainability

18 and in promoting justice for those groups who are most often affected by environmental harms. It

19 is our hope that this essay will motivate the scientific community to change its own perception of

20 what a sound and sustainable relationship between humanity and other species should be and will

21 help citizens become active environmental subjects, connected to the ecosystems around them. 


\section{1. Introduction}

23 As the $21^{\text {st }}$ century progresses, humanity faces an increasingly crowded, hotter, and more degraded

24 planet, creating an urgent need to reevaluate our relationship with the natural world. Despite

25 decades of international multidisciplinary scholarship, global biodiversity and climate

26 conventions, and concerted efforts by policymakers, human impact on the Earth' natural systems

27 has become unsustainable across a wide range of metrics (Steffen et al. 2015). We contend that to

28 preserve the species and ecosystems that humanity has interacted with and depended on for

29 millennia, scientists, government officials, decision makers, and society at large must all deepen

30 and expand their understanding of diverse ways human societies relate to and interact with non-

31 human nature.

32 Conservation is a global endeavor and is by definition a multicultural project. The international

33 conservation discourse has often been dominated by a set of worldviews that originated in Western

34 societies; this has in many cases been an obstacle to its success. The worldviews and ethical

35 constructs that scientists and society bring to problems of environmental sustainability determine

36 how situations are perceived, how problems are framed (Figure 1), and what solutions are preferred

37 or simply considered. The worldviews that presently dominate the international discourse on

38 sustainability-in particular ecosystem services and related frameworks-have emerged out of a

39 materialistic worldview that has taken a primarily anthropocentric perspective (Descola 2013).

40 These perspectives lead humans to undervalue nature, in particular the multitude of non-material

41 dimensions of the human-nature relationship, which can in turn influence the practice of ecosystem

42 management and restoration (Machaqueiro \& Grinker 2019). 
43 Our essay argues that effective conservation requires practitioners to study more deeply the diverse

44 ways that societies conceive the human-nature relationship and to put these conceptions and

45 perspectives on an equal footing to those that have historically dominated the conservation

46 discourse (Brondizio et al. 2016). An additional benefit of studying diverse alternative worldviews

47 is that it will likely improve our understanding of what constitutes a good life and will provide

48 new and alternative approaches to addressing environmental problems. The rest of our essay is

49 organized as follows. We first discuss the necessity of viewing conservation as multicultural

50 project and the significance of cultural difference in conservation. We next discuss the importance

51 of non-material values across cultures which creates an inherent weakness for conservation

52 approaches based on ecosystems services. We conclude with an agenda for the future that

53 highlights the recent global emergence of the judiciary as a powerful means to obtain more rapid

54 and effective conservation actions.

\section{2. Motivating conservation on a multicultural planet}

56 While global efforts to conserve species and ecosystems have not kept up with the pace and scale

57 of global environmental change (WWF 2018), successful conservation actions have occurred and

58 continue to occur across the globe. The success of those efforts is often determined by the degree

59 to which they align with local cultural conventions and worldviews; techniques that work in one

60 locale may find limited success elsewhere.

61 To take one particularly prominent example, the nature as service provider framework-including

62 the concept of ecosystem services (ES) and associated programs such as payments for ecosystem

63 services (PES)-has been successful in driving conservation efforts in many locales, for example,

64 wolf conservation in the Northwest of the United States and in Finland where compensation 
65 payments to ranchers have been a central part of conservation efforts (Muhly \& Musiani 2009;

66 Hiedanpää et al. 2016). Another example comes from Switzerland, where the Landscape Quality

67 Contribution program (Contribution à la qualité du paysage), which provides payments to promote

68 aspects of landscape quality such as increased biodiversity and reduced erosion, expanded in the

69 three years following its 2014 launch to the point where it was working with three quarters of

70 farmers in the country (OFAG 2017). However, in many contexts these efforts have fallen short

71 of expectations. This may partly be due to a phenomenon called motivation crowding: financial

72 incentives may crowd out pre-existing motivations for pro-environmental behavior because they

73 can promote a shift in the way people relate to their environment (Frey \& Jegen 2001). In addition

74 to motivation crowding, a broader obstacle facing PES schemes in some areas is that the idea of

75 nature as commodity implied by PES can itself be at odds with the worldviews of some

76 stakeholders whose support these programs need to succeed (Winthrop 2014).

77 On what could be considered the opposite end of the spectrum from the valuation and 78 compensation approach taken by PES programs, globally there are growing efforts where

79 nonmaterial aspects of nature as well as spiritual beliefs regarding nature take center stage in 80 motivating conservation efforts. For example, La Via Campesina, an international farmers'

81 organization created in 1993 supporting peasant empowerment and promoting sustainable

82 alternatives to large-scale agriculture, shows that alternative movements can be motivated in part

83 by a non-materialistic perspective on human well-being that is based on community integrity and

84 on respect for human and natural balance (Kohler \& Negrão 2018; Caraway 2018). More broadly,

85 small farmers and indigenous movements have worked to restore traditional knowledge, improve

86 gender equality, promote virtuous environmental practices through agroecology, and enable 
87 peasant empowerment (Perfecto et al. 2010; Altieri \& Toledo 2011). In all of these cases, 88 underlying motivation has no connection to financial incentives.

89 Sacred sites-present on every inhabited continent-are frequently a powerful motivator of 90 conservation (Dudley et al. 2009) and illustrate the diverse and important role that local belief 91 systems can play in driving nature conservation. Sacred sites have motivated conservation efforts

92 in areas as ecologically and politically diverse as tropical forests in southwestern China (Xu et al.

93 2005), broadleaved and dry forests in several Indian states (Chandrashekara \& Sankar 1998;

94 Bhagwat \& Rutte 2006), montane systems in the Ecuadorian (Carter \& Sarmiento 2011) and

95 Chilean (Herrmann 2006) Andes, riverine ecosystems in Siberia (Klubnikin et al. 2000), boreal

96 forest in Canada's western arctic (Gill et al. 2014), and the high desert of the western United States

97 (Stoffle et al. 2017). Sacred natural sites are often community focal points with specific ecosystem

98 features having particular significance, for example in spiritual ceremonies (Jeeva et al. 2006;

99 Ormsby \& Ismail 2015). The psychological and spiritual well-being of individuals and 100 communities is often linked to knowledge of the existence and integrity of sacred sites, meaning 101 that the degradation of these sites can represent an important spiritual loss to individuals (Russell 102 et al. 2013). Sacred sites can in some cases be so inextricably linked to cultural identity itself that 103 the loss of a site can result in a significant change to a society's identity (Garibaldi \& Turner 2004; 104 Vitebsky 2015).

105 Even in the absence of traditional sacred sites, or in cultures where such sites do not exist, a sense 106 of connection to place can nonetheless be an important motivator for conservation (Windsor \& 107 McVey 2005). This can be seen in the motivation of support for national parks (Weiler \& Moore 108 2013), or in the manner that an appeal to cultural tradition has been effective at motivating 109 conservation of working landscapes in countries across Europe (Fischer et al. 2012). 
110 These examples emphasize that effective conservation actions require the support of diverse

111 stakeholders who invariably perceive the world differently and have different sets of motivations.

112 The path to success lies in finding strategies that work for the worldviews and motivations of the

113 different stakeholders involved in any given project or location-not all strategies work in all

114 contexts. Improving our understanding of the diverse ways that people globally conceive of the

115 human-nature relationship, and in parallel, according those different conceptions the same respect

116 that we give our own, is an essential step to successful conservation.

117 3. Seeing the human-nature relationship differently

118 The diverse approaches to conservation described above succeeded in part because they were well-

119 aligned with the worldviews of the stakeholders whose buy-in and support mattered. While the

120 number of potential perspectives on the human-nature relationship is limitless, there are

121 nonetheless some common themes of difference that can be seen when we study the human

122 worldviews. In particular, the degree to which nature and humans are seen as separate as well as

123 the degree to which nature is considered to have intrinsic value as opposed to value that derives

124 from its utility to humans.

125 Considering intrinsic value means according a value to other species or ecosystem components 126 that is separate from the question of whether or not any human is benefited by their existence

127 (Davidson 2013). Considering intrinsic value means that non-human species are seen as ends in

128 themselves and not simply as means to benefit human well-being; it suggests that other species

129 have a right to exist that is independent of any consideration by humans (Taylor 1986; Rolston

130 1989; Batavia \& Nelson 2017). The question of intrinsic value has figured prominently in critiques

131 of conservation approaches that assign a monetary value to ecosystem services (Kumar \& Kumar 
132 2008; Wegner \& Pascual 2011). Although the effort to value ecosystem services is primarily a tool

133 for analyzing trade-offs and do not necessarily preclude a consideration of intrinsic value

134 (Costanza et al. 2017), it is nevertheless important to remain conscious of the degree to which the

135 framing of an approach-and the degree to which that framing is consistent with the worldviews of 136 stakeholders-matters when it comes to project success.

137 Findings from the environmental social sciences illustrate several areas where an economic 138 valuation of ecosystems can conflict with the worldviews of relevant stakeholders; in particular, 139 (i) in many cultures, the concepts of "nature as service provider", "ownership of nature", and 140 simply "nature" as an entity that is separate from humanity are foreign and objectionable; (ii) many 141 aspects of the human connection with nature are unquantifiable and are not amenable to trade-offs 142 with any kind of material benefit; (iii) many environmental practices are highly social in nature, 143 rendering inadequate the notion of an economic exchange among individuals as a basis for 144 evaluating those practices; and finally, (iv) many cultures and individuals consider nature to have 145 intrinsic value apart from any utilitarian value (Winthrop 2014).

146 Many Indigenous and local peoples' concepts of human-nature relationships are based on a sense 147 of spiritual, non-materialistic connection. These cosmologies and spiritualities of Indigenous 148 peoples and other groups are anchored in specific territorial contexts and offer alternative 149 worldviews and frameworks for guiding relationships between humans and the rest of nature 150 (Kealiikanakaoleohaililani \& Giardina 2016; Descola 2013). In many indigenous cultures, human 151 societies and the environment are perceived not as separate, but rather as involved in a unique 152 relationship (Berkes 2012) that embraces both spiritual and symbolic values (Caillon et al. 2017).

153 Generally, worldviews based on indigenous experience have more completely internalized the idea 154 that humans are living organisms among many others and that we depend on the rest of nature for 
155 our own survival (Saxena et al. 2018). These worldviews have helped many indigenous and local

156 people to sustainably manage their environment for decades or centuries (Johnson et al. 2016).

157 Among worldviews that provide a model for the human-nature relationship, animism deserves 158 special attention. The first understanding and description of animism was basically that of a 159 religion attributing a soul to both animate and inanimate objects. The definition has since evolved 160 to embrace the so-called "shamanic complex", a worldview mainly found in Siberia, North-Eastern 161 America, South America, and among several aboriginal peoples of South-Eastern Asia (Descola 162 2013). Animism has been considered the antithesis of Naturalism, the Western worldview that 163 considers humans (Culture) separate from Nature-the rest of the living beings. Animist 164 spiritualities are based on the idea that "humanity" does not characterize or constitute a species 165 (ours), but rather is a condition of existence shared among all living beings. In contrast to 166 Naturalism and the associated Nature-Culture dichotomy, animism is based on the idea that all 167 living beings share the same culture, while their bodies differ according to their ecological 168 behavior (Viveiros de Castro 2015). In animist worldviews, living beings-humans and all others169 engage with each other in social relationships that include exchange, reciprocity, predation, and 170 even sexual relations. special rights to humans above other beings (Descola 2013).

171 Spiritual or emotional bonding with nature is not unique to animist cultures. The importance of 172 place and sense of place in maintaining human well-being in both indigenous and non-indigenous 173 cultures is documented in a rich and diverse literature (Windsor \& McVey 2005 and references 174 therein). Whether it be termed "place attachment," "settlement identity," "homelands," or 175 "landscape of home," a sense of place provides individuals and groups with a sense of belonging, 176 of security, and of control (Windsor \& McVey 2005). These perspectives are not immutable but 177 can in fact be promoted: time spent interacting with nature leads many individuals to report a sense 
178 of belonging and spiritual fulfilment, or a sense of the presence of something greater (Vorkinn \&

179 Riese 2001). This spiritual connection-which has been shown to be relatively independent of an

180 individual's belief system-can result in emotional or spiritual harm being experienced by

181 individuals in response to degradation of natural areas (Cunsolo Willox et al. 2012). On the

182 positive side, these connections can lead to individuals taking greater responsibility for the

183 conservation and integrity of natural places (Heintzman 2003, 2012).

184 4. An agenda for culturally-responsive conservation

185 To be effective, conservation policies and programs need to take a pluralistic approach and 186 recognize cultural differences in what motivates people in their relationship with nature.

187 Conservation that takes seriously all worldviews and all perspectives on the human-nature 188 relationship is strategic, practical, and ethical. It is strategic because it will improve program buy189 in; practical because it increases the likelihood that practitioners will identify locally-appropriate 190 approaches; and ethical because it commits to the inclusion of views that too frequently are

191 marginalized. Conservation programs and policies will see greater success if they invest in 192 understanding local worldviews and if they give a place at the table to stakeholders with diverse 193 worldviews. In recent decades, conceptions of nature as service provider have perhaps taken an 194 oversize role as the guiding worldview in policy discussions around conservation, particularly at 195 the international level. Recently, the concept of nature's contributions to people (NCP) has 196 provided an alternative to ecosystem services (ES) that provides an avenue where cultural 197 differences are considered in the valuation of what nature provides to humanity (Diaz et al. 2018); 198 however, NCP nonetheless retains the ES focus on benefits to humans. A more holistic approach 199 to conservation-that we argue would be a more effective approach-would in particular provide 
more space for worldviews that recognize the intrinsic value or the inherent rights of nature. A

201 recognition of the rights of nature would be particularly impactful in its influence on national and

202 international jurisprudence.

203 The recently-completed IPBES Land Degradation and Restoration Assessment (IPBES 2018)

204 contends that the scientific community, government officials, decision-makers, and civil society

205 need to move beyond a narrative of nature as a commodity in order to better understand how

206 individuals and societies conceive their relationship with nature and how those relationships with

207 nature affect human well-being in both material and nonmaterial ways. A richer engagement with

208 diverse worldviews and perspectives on human-nature connection can guide the development of 209 policy and management options that more effectively avoid and reverse environmental 210 degradation. We also believe that there is an urgent need to reconnect citizens with Nature.

211 Alternative but potentially universal concepts of human-nature relationships have already begun

212 to diffuse into societies in a variety of ways. At a global level, the concept of "environmentality"

213 (Agrawal 2005) acknowledges the rise of "environmental subjects": people who no longer accept

214 remaining passive while the global environment is threatened (Fletcher 2010). At the national

215 level, other alternative concepts can be found in the Constitution of Ecuador (2008) and in Bolivia

216 (Law No. 071, of Mother Earth Rights, and Law No. 300, the Framework Law of Mother Earth

217 and Integral Development for Living Well) which have integrated the concept of "Buen vivir" or

218 "Vivir bien" in order to recognize that individuals depend on nature. These concepts regard land

219 as a living territory with multiple dimensions-both material and immaterial-and define human

220 societal well-being not only in terms of work and material consumption, but instead in terms of

221 social connection, community ties, and harmony with nature (Acosta 2008; Walsh 2010). 
222 Movements such as La Via Campesina and new legal frameworks such as those in Ecuador and

223 Bolivia show that it is possible to shift from a worldview where land is perceived as a commodity

224 to another where social organization is based on an ethic of natural balance as a condition for living

225 a good life. A growing number of global consumers are knowledgeable and supportive of efforts

226 to realign our relationship with the natural world and alter their consumption patterns accordingly.

227 However, even with radical changes to consumption patterns, citizens acting individually will not

228 be sufficient to shift human society to a more sustainable relationship with nature. In many

229 countries, the judiciary is playing an increasingly important role as a tool for citizens to influence

230 policy and decision-makers (Banda \& Fulton 2017). A recent report by the United Nations

231 Environment Program documented nearly 900 legal cases initiated worldwide that raise issues of

232 law or fact relating to climate change; to date, the majority of these have related to claims of

233 insufficient government efforts in reducing greenhouse gas emissions (UNEP 2017). Among the

234 most prominent of these is the Juliana vs. United States suit, the complainants of which are 21

235 children and teenagers supported by the NGO Our Children's Trust. The Juliana complaint asserts

236 that because of its lack of sufficient action to mitigate emissions, the US Government has violated

237 the complainants' constitutional rights to life, liberty, and property and has also violated the federal

238 public trust doctrine (Blumm \& Wood 2017).

239 Litigation related to climate change and to other aspects of the environment has often sought to 240 broaden our conceptions of what rights humans have. For example, in many countries, courts are

241 becoming more receptive to the idea that citizens have a right to a stable climate system and to 242 safety from harm resulting from climate change and that citizens may seek legal redress if those 243 rights are violated (Peel \& Osofsky 2018). As an example, the circuit court judge in the Juliana 244 vs. USA suit wrote in a decision that "the right to a climate system capable of sustaining human 
245 life is fundamental to a free and ordered society" (Juliana v. United States, sec III-A). Additionally,

246 climate litigation has in some cases sought to broaden our conceptions of who-among humans-

247 can claim these rights. Future generations, and the duty of care that the present generation owes

248 them, are increasingly referenced in litigation such as Juliana (Blumm \& Wood 2017). A

249 particularly important development in the legal standing of future generations came in the case of

250 Rabab Ali v. Pakistan when the Pakistani Supreme Court allowed a climate change lawsuit to

251 proceed that specifically identified future generations as a claimant (Banda \& Fulton 2017). Courts

252 have long played a role in ensuring protection for marginalized groups, and this has consistently

253 been the case when it comes to environmental justice; there are abundant examples of individuals

254 and groups successfully using the courts to protect indigenous rights to lands, to limit industrial

255 pollution, and to reduce other environmental harms (Osofsky 2005).

256 As much as these lawsuits are ground-breaking in many ways, they nonetheless remain grounded

257 in a worldview where the only rights being considered are those of humans-even if the humans

258 being considered are individuals who are yet to be born. The risk of reliance on such an

259 anthropocentric vision of humanity's relationship with the natural world is that it is not sufficiently

260 balanced by moral or ethical principles that would provide an alternate means of respect and

261 protection for non-human components of nature, including individual animals (Braverman 2018).

262 As Claude Lévi-Strauss puts it: "If man possesses rights as a living being, then it follows

263 immediately that these recognized rights of humanity as a species will encounter their natural

264 limits in the rights of other species. Thus, the rights of mankind stop whenever and wherever their

265 exercise imperils the existence of other species" (Lévi-Strauss 1985: 282). Lévi-Strauss advocated

266 for a "well-conceived humanism" that would leave space on the planet to other species.

267 Considering the interests of non-humans and allowing them to evolve and adapt would be an 
268 important step in a more inclusive human ethic and a first step to acknowledging nature's intrinsic

269 value (Burdon 2011). From these new principles could derive new laws framing a new

270 conservation ethic and legal framing for a renewed ecological governance (Wooley 2014;

271 Kauffman \& Martin 2018).

272 Indeed, there are examples where the rights of non-human species and of nature generally have 273 already been codified in law. This includes the adoption by the New Zealand Parliament of an Act 274 by which Te Urewera National Park became not simply a park but also a legal entity with "all the 275 rights, powers, duties, and liabilities of a legal person (Ruru 2014); the Colombian Supreme Court 276 of Justice instructing the Government to take action to halt and reverse the degradation of the 277 Amazon forest because of the intrinsic right of the forest to exist (García Pachón 2018). These 278 laws codify the idea that the environment should be defended for its own sake and that have 279 acknowledged both the spiritual and intrinsic values of nature (Knauß 2018). In some cases, the 280 shift to these laws that enshrine the rights of nature have been supported by conceptions of the 281 rights of nature that are products of or influenced by non-western cosmologies (Kauffman \& 282 Martin 2018).

283 "Ecological solidarity," an emerging concept in France, could provide a broad-reaching legal 284 framework for the recognition of the inherent value of nature as well as the recognition of the 285 ethical duties that humans have towards nature and towards future generations. As a legal 286 principle, ecological solidarity relies on the existence of moral relationships between humans and 287 non-humans. This kind of coupling is very similar to the spiritual dimension of the 288 human/environment relationship in some indigenous societies and especially that relationship as 289 it is framed by animist worldviews. Originally conceived as a way to consider biological 290 connections around protected areas, it now conveys a more global message based on the 
291 straightforward idea that humans are part of their environment. Ecological solidarity operates on

292 three dimensions: it recognizes the planetary-scale interconnections of ecosystems and ecological

293 process, it encourages intergovernmental negotiations based on global and mutual solidarity, and

294 it promotes a moral framing that emphasizes the common fate of humankind and all living beings

295 (Thompson et al. 2011; Mathevet et al. 2018). Establishing this principle in more countries around

296 the world would more broadly establish the idea that our current generation owes a duty of care to

297 future generations and to other species, requiring legislators, judges, and other actors of the law to

298 take into account the long-term consequences of their actions on nature and future generations. By

299 focusing on the relationship that humans have with the rest of nature (Mathevet et al. 2018),

300 ecological solidarity is a framework that is inherently adaptable to diverse ways of defining what

301 that relationship is.

302 While the spiritual and ethical worldviews held by individuals are beyond the reach of a policy or

303 a legal framework, we believe that research and outreach-especially in increasing humanity's

304 contact with nature and in increasing engagement with worldviews that value nature's non-

305 material and intrinsic values-would create conditions where more sustainable concepts of human-

306 nature relationships can emerge: concepts that emphasize values of cooperation and solidarity over

307 competition and reduce the degree to which high levels of consumption are seen as a symbol of a

308 successful life. Alternative concepts already exist, with more adherents each year, that are based

309 on a moral economy (Edelman 2005). This economy values social relations, limited and local

310 consumption, respect, and solidarity, and is inspired by traditional populations and practices. Its

311 aim is to consolidate social cohesion through community mutual aid and sustainable production-

312 consumption systems (Lebel \& Lorek 2008; Tukker et al. 2008). A pluralistic approach to

313 environmental stewardship-one that engages seriously with diverse conceptions of the human- 
314 nature relationship-is our best chance to motivate and to lead societies toward a more sustainable,

315 equitably shared, and environmentally just future.

316

Page 15 of 26 


\section{References}

318 Acosta A. 2008. The Good Life, an Opportunity for Construction [El Buen Vivir, una oportunidad por construir]. Ecuador Debate:33-47.

Agrawal A. 2005. Environmentality: technologies of government and the making of subjects. Duke University Press, Durham, NC.

Altieri MA, Toledo VM. 2011. The agroecological revolution in Latin America: Rescuing nature, ensuring food sovereignty and empowering peasants. Journal of Peasant Studies 38:587-612.

Banda ML and Fulton CS. 2017. Litigating Climate Change in National Courts: Recent Trends and Developments in Global Climate Law. Environmental Law Reporter 47:1012110134.

Batavia C, Nelson MP. 2017. For goodness sake! What is intrinsic value and why should we care? Biological Conservation 209:366-376.

Berkes F. 2012. Sacred Ecology. Routledge, London.

Bhagwat SA, Rutte C. 2006. Sacred groves: Potential for biodiversity management. Frontiers in Ecology and the Environment 4:519-524.

333 Blumm, M. C.; Wood, M. (2017). No ordinary lawsuit: Climate change, due process, and the public trust doctrine. American University Law Review 67:1-88. 
335 Braverman, I. (2018). Law's Underdog: A Call for More-than-Human Legalities. Annual Review 336 of Law and Social Science 14:127-144.

337

Brondizio ES et al. 2016. Re-conceptualizing the Anthropocene: A call for collaboration. Global 338 Environmental Change 39:318-327.

339 Burdon P. 2011. Exploring wild law: The philosophy of earth jurisprudence. Wakefield Press, $340 \quad$ Adelaide.

341 Caillon S, Cullman G, Verschuuren B, Sterling EJ. 2017. Moving beyond the human-nature dichotomy through biocultural approaches: Including ecological well-being in resilience indicators. Ecology and Society 22.

344 Caraway, R. 2018. The Spiritual Dimensions of the Permaculture Movement in Cuba. Religions, 345

346 Carter LE, Sarmiento FO. 2011. Otavaleños and Cotacacheños: Local Perceptions of Sacred Sites for Farmscape Conservation in Highland Ecuador. Journal of Human Ecology

349 Chandrashekara UM, Sankar S. 1998. Ecology and management of sacred groves in Kerala, $350 \quad$ India. Forest Ecology and Management 112:165-177.

351 Costanza R, de Groot R, Braat L, Kubiszewski I, Fioramonti L, Sutton P, Farber S, Grasso M. 352 2017. Twenty years of ecosystem services: How far have we come and how far do we 353 still need to go? Ecosystem Services 28:1-16. 
354 Cunsolo Willox A, Harper SL, Ford JD, Landman K, Houle K, Edge VL. 2012. "From this place and of this place:" Climate change, sense of place, and health in Nunatsiavut, Canada. Social Science and Medicine 75:538-547.

Davidson MD. 2013. On the relation between ecosystem services, intrinsic value, existence value and economic valuation. Ecological Economics 95:171-177.

Descola P. 2013. Beyond Nature and Culture. University of Chicago Press, Chicago.

Diaz S et al. 2018. Assessing nature's contributions to people. Science 359:270-272.

Dudley N, Higgins-Zogib L, Mansourian S. 2009. The links between protected areas, faiths, and sacred natural sites. Conservation Biology 23:568-577.

Edelman M. 2005. Bringing the Moral Economy back in ... to the study of 21 st-century transnational Peasant movements. American Anthropologist 107:331-345.

E1 Espectador 2018. La Amazonía colombiana tiene los mismos derechos que una persona. Available from https://www.elespectador.com/noticias/judicial/la-amazonia-colombianatiene-los-mismos-derechos-que-una-persona-articulo-748340 (accessed July 2018).

Fischer, J. , Hartel, T. and Kuemmerle, T. (2012), Conservation policy in traditional farming landscapes. Conservation Letters 5:167-175.

Fletcher R. 2010. Neoliberal environmentality: Towards a poststructuralist political ecology of the conservation debate. Conservation and Society 8:171. 
372 Frey, B. S., \& Jegen, R. (2001). Motivation crowding theory. Journal of economic surveys 15:589-611.

374 375

García Pachón, M. P. 2018. La Corte Suprema de Justicia reconoce como sujeto de derechos a la Amazonia Colombiana. Blog del Departamento de Derecho del Medio Ambiente, Universidad Externado de Colombia, April 12, 2018. $\underline{\text { https://medioambiente.uexternado.edu.co/la-corte-suprema-de-justicia-reconoce-como- }}$ sujeto-de-derechos-a-la-amazonia-colombiana/ Retrieved on Jan. 19, 2019.

Garibaldi A, Turner N. 2004. Cultural keystone species: Implications for ecological conservation and restoration. Ecology and Society 9:1.

Gill H, Lantz T. 2014. A community-based approach to mapping Gwich'in observations of environmental changes in the lower peel river watershed, NT. Journal of Ethnobiology 34:294-314.

Harmsworth G, Roskruge N. 2014. Indigenous Māori values, perspectives and Knowledge of soils in Aotearoa-New Zealand: Beliefs, and Concepts of Soils, the Environment and Land. Pages 111-126 in G. J. Churchman and E. R. Landa, editors, The Soil Underfoot: Infinite Possibilities for a Finite Resource. CRC Press, Boca Raton, FL.

Heintzman P. 2003. The wilderness experience and spirituality: What recent research tells us. Physical Education, Recreation \& Dance 74:27-32.

Heintzman P. 2012. The spiritual dimension of campers' park experience: Management implications. Managing Leisure 17:291-310. 
392

393

394

395

396

397

398

399

400

401

402

403

404

405

406

407

408

409

410

411

Herrmann TM. 2006. Indigenous knowledge and management of Araucaria araucana forest in the Chilean Andes: Implications for native forest conservation. Biodiversity and Conservation 15:647-662.

Hiedanpää J, Kalliolevo H, Salo M, Pellikka J, \& Luoma M. 2016. Payments for Improved Ecostructure (PIE): Funding for the Coexistence of Humans and Wolves in Finland. Environmental management 58:518-533.

IPBES. 2018. Summary for policymakers in R. Scholes et al., editors. Thematic assessment report on land degradation and restoration of the Intergovernmental Science-Policy Platform on Biodiversity and Ecosystem Services. IPBES Secretariat, Bonn.

Jeeva S, Mishra B, Venugopal N, Kharlukhi L, Laloo R. 2006. Traditional knowledge and biodiversity conservation in the sacred groves of Meghalaya. Indian Journal of Traditional Knowledge 5:563-568.

Johnson JT, Howitt R, Cajete G, Berkes F, Louis RP, Kliskey A. 2016. Weaving Indigenous and sustainability sciences to diversify our methods. Sustainability Science 11:1-11.

Juliana v. United States, No. 6:15-CV-01517-TC, 2016 WL 6661146, 46 ELR 20175 (D. Or. Nov. 10, 2016).

Kauffman, C. M., \& Martin, P. L. 2018. Constructing Rights of Nature Norms in the US, Ecuador, and New Zealand. Global Environmental Politics 18:43-62.

Kealiikanakaoleohaililani K, Giardina CP. 2016. Embracing the sacred: an indigenous framework for tomorrow's sustainability science. Sustainability Science 11:57-67. 
412 Klubnikin K, Annett C, Cherkasova M, Slushin M, Fotieva I. 2000. The sacred and the scientific:

413 Traditional ecological knowledge in Siberian river conservation. Ecological Applications 10:1296-1306.

415 Knauß, S. 2018. Conceptualizing Human Stewardship in the Anthropocene: The Rights of Nature in Ecuador, New Zealand and India. Journal of Agricultural and Environmental Ethics 1-20.

418 Kohler F, et al. 2018. Concepts and Perceptions of Land Degradation and Restauration in R. Scholes et al., editors. Thematic assessment report on land degradation and restoration.

421 Kohler F, Negrão M. 2018. The homeopathy/agroecology nexus: a discourse-centered analysis in a Brazilian agrarian settlement. Dialectical Anthropology:1-15.

423 Kumar M, Kumar P. 2008. Valuation of the ecosystem services: A psycho-cultural perspective. $424 \quad$ Ecological Economics 64:808-819.

425 Lebel L, Lorek S. 2008. Enabling sustainable production-consumption systems. Annual Review 426 of Environment and Resources 33:241-275.

427 Lévi-Strauss C. 1985. The view from afar. Basic Books, New York.

428 Mathevet, R., Bousquet, F., Larrère, C., \& Larrère, R. (2018). Environmental Stewardship and 429 Ecological Solidarity: Rethinking Social-Ecological Interdependency and Responsibility. $430 \quad$ Journal of Agricultural and Environmental Ethics 31:605-623. 
431 Muhly B, Musiani M. 2009. Livestock depredation by wolves and the ranching economy in the

432 Northwestern U.S. Ecological Economics 68:2439-2450.

433 OFAG - Office fédéral de l'agriculture (2017). Rapport d'évaluation sur le programme de 434 paiements directs relatif aux contributions à la qualité du paysage. Département fédéral 435 de l'économie, de la formation et de la recherche DEFR, Confédération suisse.

436 Ormsby AA, Ismail SA. 2015. Cultural and ecological insights into sacred groves: Managing 437 timber resources for improved grove conservation. Forests Trees and Livelihoods $438 \quad 24: 244-258$.

439 Osofsky, H. M. (2005). Learning from environmental justice: new model for international 440 environmental rights. Stanford Environmental Law Journal 24:71-150.

441 Peel, J., \& Osofsky, H. (2018). A Rights Turn in Climate Change Litigation? Transnational $442 \quad$ Environmental Law 7:37-67.

443 Perfecto I, Vandermeer J. 2010. The agroecological matrix as alternative to the land$444 \quad$ sparing/agriculture intensification model. PNAS 107:5786-5791.

445 Rolston H. 1989. Environmental ethics: duties to and values in the natural world. Temple $446 \quad$ University Press, Philadelphia, PA.

447 Ruru J. 2014. Tūhoe-Crown settlement - Te Urewera Act 2014. Māori Law Review, October 4482014. 
449

450

451

452

453

454

455

456

Russell R, Guerry AD, Balvanera P, Gould RK, Basurto X, Chan KMA, Klain S, Levine J, Tam J. 2013. Humans and nature: How knowing and experiencing nature affect well-being. Annual Review of Environment and Resources 38:473-502.

Saxena, A. K., Chatti, D., Overstreet, K., \& Dove, M. R. 2018. From moral ecology to diverse ontologies: relational values in human ecological research, past and present. Current Opinion in Environmental Sustainability 35:54-60.

Steffen W et al. 2015. Planetary boundaries: Guiding human development on a changing planet. Science 347:6223.

Stoffle R, Van Vlack K, Arnold R, Benson GB. 2017. Cant of Reconquest and the Struggle for Restoring Sustainability of the Southern Paiutes. Pages 231-246 in M.-T. Albert, F. Bandarin, and A. Pereira Roders, editors. Going Beyond: Perceptions of Sustainability in Heritage Studies No. 2. Springer International Publishing, Cham.

Taylor PW. 1986. Respect for Nature: A Theory of Environmental Ethics. Princeton University Press, Princeton, NJ.

Thompson JD, Mathevet R, Delanoë O, Gil-Fourrier C, Bonnin M, Cheylan M. 2011. Ecological solidarity as a conceptual tool for rethinking ecological and social interdependence in conservation policy for protected areas and their surrounding landscape. Comptes Rendus - Biologies 334:412-419.

Tukker A, et al. 2008. Fostering change to sustainable consumption and production: an evidence based view. Journal of Cleaner Production 16:1218-1225. 
469 United Nations Environment Programme. 2017. The Status of Climate Change Litigation - A

$470 \quad$ Global Review. Nairobi.

471 Vitebsky P, Alekseyev A. 2015. What is a reindeer? Indigenous perspectives from northeast $472 \quad$ Siberia. Polar Record 51:413-421.

473 Viveiros de Castro E. 2015. Cannibal metaphysics. University of Minnesota Press, Minneapolis.

474 Vorkinn M, Riese H. 2001. Environmental concern in a local context. The significance of place 475 attachment. Environment and Behavior 33:249-263.

476 Walsh C. 2010. Development as Buen Vivir: Institutional arrangements and (de)colonial 477 entanglements. Development 53:15-21.

478 Wegner G, Pascual U. 2011. Cost-benefit analysis in the context of ecosystem services for human well-being: A multidisciplinary critique. Global Environmental Change 21:492-504.

480 Weiler, B., Moore, S.A. and Moyle, D.B. (2013) Building and sustaining support for national 481 482 parks in the 21st century: Why and how to save the national park experience from extinction. Journal of Park and Recreation Administration 31:115-131.

483 Windsor JE, McVey JA. 2005. Annihilation of both place and sense of place: The experience of 484 the Cheslatta T'En Canadian First Nation within the context of large-scale environmental 485 projects. Geographical Journal 171:146-165.

486 Winthrop RH. 2014. The strange case of cultural services: Limits of the ecosystem services 487 paradigm. Ecological Economics 108:208-214. 
488 Woolley, O. 2014. Ecological Governance. Cambridge University Press.

489 WWF. 2018. Living Planet Report - 2018: Aiming Higher. Grooten, M. and Almond, R.E.A. 490 (Eds). WWF, Gland, Switzerland.

491 Xu J, Ma ET, Tashi D, Yongshou F, Zhi L, Melick D. 2005. Integrating Sacred Knowledge for 492 Conservation Culture and Land Scape in Southwest China. Ecology and Society 10. 


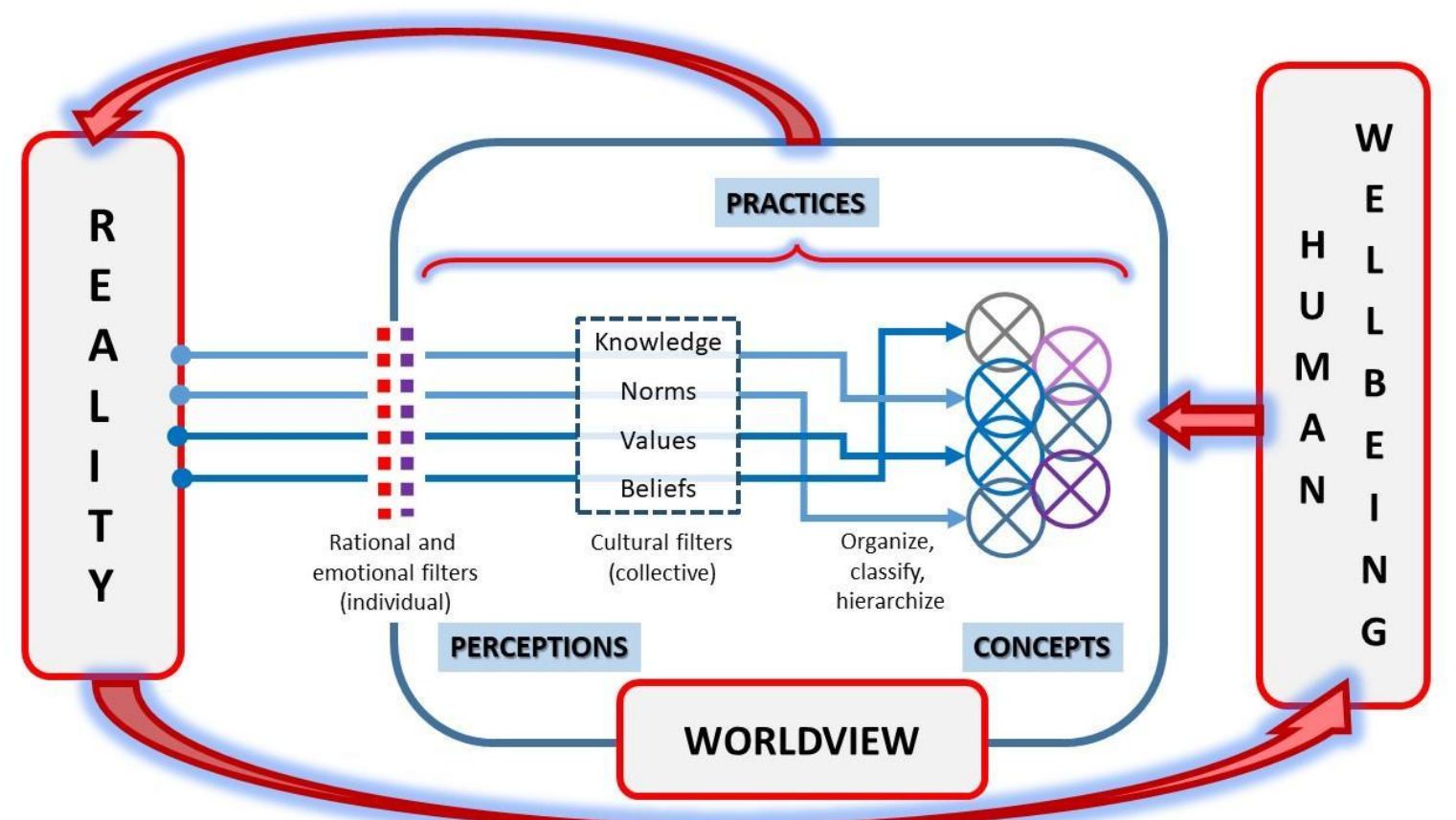

Figure 1: Perceptions are organized into a hierarchy of concepts dependent on collective systems of knowledge, norms, values and beliefs. These concepts in turn guide cultural, governance and land management practices, as well as resource use and consumer behaviors. al. 2018). 